\author{
Military Technical College \\ Kobry El-Kobbah, \\ Cairo, Egypt.
}

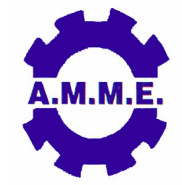

\title{
QUALITY IMPROVEMENT OF THERMOFORMING PROCESS USING SIX SIGMA METHODOLOGY
}

\author{
M. S. Nagy ${ }^{*}$ M. A. Sharaf El-Deen ${ }^{\star *}$ and A. R. El-Desouky ${ }^{\star \star *}$
}

\begin{abstract}
The importance of quality has been recognized in the business environment in order to obtain or produce higher quality products. In a manufacturing environment, process tends to produce defects due to various reasons which can be improved by identifying and eliminating them using Six Sigma methodology. In this paper, DMAIC (Define, Measure, Analyze, Improve, and Control) approach has been used to reduce the number of rejected thermoformed inner liners of home refrigerator. In define phase, problem was defined by determining the main category of defects. In measure phase, data were collected to determine the current performance and the process capability. In analyzing phase, root causes of main defects were identified. In improvement phase, corrective actions and solutions were determined and finally in control phase, various procedures were implemented for tracking the process and putting it under control. The results showed that process quality was improved through reduction in defects from about 123000 ppm to about 55000 ppm.
\end{abstract}

\section{KEY WORDS}

Six Sigma, Quality Improvement, DMAIC, Thermoforming Process, SIPOC, MINITAB 16.

\footnotetext{
Researcher for M. Sc. Degree, Dept. of Prod. Eng. and Mech. Design, Faculty of Engineering, Menoufiya University, Egypt. Email: msfnagy@hotmail.com.

** Associate Professor, Dept. of Prod. Eng. and Mech. Design, Faculty of Engineering, Menoufiya University, Egypt.

*** Professor, Dept. of Prod. Eng. and Mech. Design, Faculty of Engineering, Menoufiya University, Egypt
} 


\section{INTRODUCTION}

In recent years, an increasing number of companies have used different types of quality programs to increase internal and external customer satisfaction as well as to reduce quality cost. Process improvement has often been accomplished through an integrated approach, using problem-solving techniques such as total quality management (TQM) and classic statistical analysis. Among all these programs, Six Sigma is perhaps the most widely-applied. There are many documented case studies of organizational applications of Six Sigma, where large-scale improvements in variability of processes to meet the customer satisfaction [3]. Six Sigma is a highperformance, data-driven approach to analyze the root causes of business problems and solving them [2]. Six Sigma, a statistically-based quality improvement program, helps to improve business processes by reducing the waste and costs related to poor quality, and by improving the efficiency and effectiveness of processes [3]. In Six Sigma approach, there are two tools namely: DMAIC and DFSS (Design For Six Sigma). The overall approach to solve problem by using DMAIC methodology includes conversion of practical problem into statistical problem and finding statistical solution. These statistical solutions are converted into practical solutions and are implemented properly in the organizations [2].

The company involved in this study is a home appliances manufacturing company. It is one of leading companies in Egypt and North Africa. Home refrigerator is considered one of the most important products of this company. The manufacturing of home refrigerator consists mainly of two sets of operations, first is for parts manufacturing and the other is for assembly. This paper presents the application of Six Sigma to improve quality in thermoforming processes which produce the inner liner of home refrigerator.

In home refrigerator manufacturing, the defective inner liner from thermoforming process has a serious effect and so is one of the main causal factors of a defective refrigerator. The aims of this research are to identify the quality characteristics in thermoforming process, to decide the factors which affect the quality variation of thermoformed parts and to determine the improvement plan for increasing thermoforming process capability and decreasing defect rate using six sigma method.

\section{CASE STUDY}

In this discussion, we will describe DMAIC phases as a basic concept on doing quality improvement by using Six Sigma methodology.

\section{Define Phase}

This phase determines the objective and scope of the study. Information about the present processes is collected, determination of customers and deliverables to customers are also determined. 


\section{Project charter and process flow map}

The Project Charter defines the scope, objectives, and overall approach for the work to be completed. It is a critical element for initiating, planning, executing, controlling, and monitoring the study [2]. Table 1 shows the details of our project charter. Process flow map used is shown in Fig.1, which represents present flow of the manufacturing process and its functions.

\section{Sipoc}

SIPOC is a tool used to develop a high-level understanding of the process that is under study, including the upstream and downstream links [4]. SIPOC stands for:

Supplier (S): The person or company that provides the input to the process (e.g. raw materials, labor, machinery, information, etc.). The supplier may be both external and internal to the company. Input (I): The materials, labor, machinery, information, etc. required for the process. Process (S): The internal steps necessary to transform the input to output. Output $(O)$ : The product (both goods and services) being delivered to the customer. Customer $(C)$ : The receiver of the product. The customer could be the next step of the process or a person or organization [5]. Table 2 describes the SIPOC diagram representing the thermoforming process.

The critical to quality (CTQ) tree is used for identifying critical to quality (CTQ) characteristics, features by which customers evaluate a product or service [5]. This simple tool helps to move from general needs of the customers to the more specific requirements [1]. The critical to quality (CTQ) tree of the present study is outlined in Fig. 2.

\section{Measure Phase}

The measure phase serves to validate or redefine the problem. It is also the phase where the search for root causes begins by determining the key data required to narrow down the problem to its major factors or vital few root causes [6]. To meet this objective, the past information for thermoforming process was collected and illustrated in Fig. 3.

In thermoforming process, rejected inner liner was classified into three main categories: defects due to extruded sheet, defects due to vacuum forming process and defects due to trimming process. Figure 4 describes participation of each category in total reject ratio. The results showed that the main category of defects was defects due to sheet. Since we had two types of inner liners (A and B) we classified sheet defects based on material type. Material A was contributed with $81 \%$ of total defects due to sheet whereas material B with only $19 \%$.

Since defects due to sheet have many forms like moisture, non homogeneity of wall thickness of thermoformed inner liner, hard particles in sheet layers and others. A Pareto chart was made to identify the vital few defects and the data are given in Fig. 5 . A base line was needed for evaluating the improvement expected in the vital few defects as illustrated in Figs. 6 and 7. 


\section{Analyze Phase}

In the analyze phase, practical business or operational problems are turned into statistical problems [6]. One of the key objectives of Analyze phase is to determine the drivers, the little $x$ 's that correlate to the customer requirements (CTQ) and significantly influence the process or design [7]. For doing right analysis of the defects determined in the measure phase, the cross functional team (vacuum forming engineer, sheet extrusion engineer, machine operators, maintenance engineers and quality control engineer) made a brainstorming session to get all potential root causes of the defects. After efficient brainstorming, 18 ideas came out as the possible causes of the hard particles defect. These initial ideas were shown in Fig. 8. Brainstorming session conducted again for non uniform thickness defect and came out with 19 ideas.

\section{Improve Phase}

In this phase the team generates, selects and implements a set of solutions to improve process performance. It is recommended that when implementing solutions, the project team prioritizes the solutions and implements them one at a time or in groups, immediately following implementation of the solutions with a recalculation of sigma [8].Team determined priority of improvement plan items by using Failure Mode and Effects Analysis (FMEA). Failure mode is defined as the manner in which the process could potentially fail to meet the process requirements. It is a description of the nonconformance at that specific operation [9]. It was considered as defects in our case study. Potential effects of failure are defined as the effects of the failure mode on the customer(s) [9]. Potential causes are derived from cause and effect diagram in the analyze phase. Severity is the rank associated with the most serious effect for a given failure mode, and is subjected to a rating 1 to 10 on scale [9]. Each of the causes is subjected to a rating 1 to 10 scale on likelihood of occurrence and detection, with high numbers being more problematic, The Risk Priority Number (RPN) is calculated as the product of those three scales (severity,occurrence and detection) [1]. Based on the score of RPN and criticality number (Criticality = Occurrence $X$ Severity), the highest priority is the highest RPN number. Table 3. shows the results of FMEA and the related recommended actions.

Design of Experiments (DOE) is a series of techniques that involves the identification and control of parameters or variables (termed 'factors' ) that have a potential impact on the output (termed 'response ') of a process with the aim of optimising the design or the process [5]. The experiment was performed for 3 factors ( service time for screen filter before changing, screen filter mesh number and temperature of dies heaters) at two levels identified in Table 4. The results shown that changing period was the significant parameter and the associated recommended levels for parameters setting is derived from parameter main effect chart, Fig. 9, which achieve lower value of mean defects ratio.

The recommended actions mentioned in FMEA Table were performed effectively and that was confirmed by results shown in associated figures as follows:

Fig. 10, shows the status of feed die and screw before and after cleaning and maintenance, Fig. 11, clarifies the improvement achieved in total defect percent as a performance indicator in refrigerator inner liner manufacturing department 
(thermoforming department) during and after applying six sigma project for quality improvement, Fig. 12, represents a run chart for tracing the hard particles defect as it is one of the major defects required to be reduced and the improvement achieved is clear during and after six sigma application, Fig. 13, describes the process capability analysis of sheet thickness measurements after using one material (type B) as it is considered the main cause in thickness homogeneity of vacuum formed inner liner, comparing these results with those shown in Fig. 7, clarifies the improved capability of producing uniform sheet thickness using one material type.

\section{Control Phase}

The control phase establishes the ongoing controls necessary to sustain the benefits from the Six Sigma project. The following actions are taken by the team and the related departments for sustaining the gain and controlling the process at the improved level of performance:

1- Making a periodic maintenance and cleaning plan for machine parts as follows :

\begin{tabular}{|c|c|c|}
\hline Unit name & Maintenance period & Responsibility \\
\hline T- die & every 3 months & $\begin{array}{c}\text { sheet extrusion operating } \\
\text { team }\end{array}$ \\
\hline feed die & every 6 months & $\begin{array}{c}\text { sheet extrusion operating } \\
\text { team }\end{array}$ \\
\hline screw and barrel & every 2 years & maintenance team \\
\hline
\end{tabular}

2- Modifying standard operation procedure (SOP) with the optimized setting values for screen changing period to be every 8 hours, screen filter mesh number to be \#80 and feeding dies heaters to be at $230{ }^{\circ} \mathrm{C}$.

3- Establishing a variable control chart $(X$ bar- $R)$ for sheet thickness monitoring in sheet extrusion process, the initial control limits are $(\mathrm{UCL}=2.059$ and $\mathrm{LCL}=2.035 \mathrm{~mm}$ ) whereas specification for sheet thickness are (USL=2.06 and $\mathrm{LSL}=2.00 \mathrm{~mm}$ ), revised control chart with derived control limits computed by Minitab software shown in Fig. 14.

4- Establishing a calibration periodic plan for measurement tool (micrometer) used for measuring sheet thickness every 6 months.

\section{CONCLUSION}

Six sigma methodology has been used to reduce defects ratio of home refrigerator inner liner thermoforming process and to improve process performance. It was found that the main category of defects is sheet defects, in particular two main defects hard particles and nonuniform thickness. By using six sigma DMAIC approach a breakthrough in reducing defects was achieved, as was confirmed with results as follows:-

1- Defects ratio decreased from about $12 \%$ (123000 ppm) to about $5.5 \%$ (55000 ppm) and for sheet defects mainly from (95000 ppm) to about (29000 ppm). 
2- Process capability improved from $(\mathrm{CPK}=0.3$ to 0.76$)$ with inspector training and measurement device calibration regularly.

3- Machine parts maintenance and cleaning has a strong relation and great effect on hard particles defect.

Benefits of implementation have been found to be enormous in this case study. However, further research is possible in the same direction of decreasing defects ratio. As regarding to sigma level calculation, the implementation of six sigma in refrigerator inner liner thermoforming process is still below standard (6 sigma level at $3.4 \mathrm{ppm})$.

\section{REFERENCES}

[1] Ditahardiyani, P.,Ratnayani and Angwar M.,"The Quality Improvement of Primer Packaging Process Using Six Sigma Methodology."Journal teknik industry, vol. 10, no. 2, pp. 177-184, (2008).

[2] Khekale, S.N., Chatpalliwar, A.S. and Thakur, N.V., "Minimization of Cord Wastages in Belt Industry Using DMAIC." International Journal of Engineering Science and Technology, vol. 2(8), pp. 3687-3694, (2010).

[3] Hung, H.C. and Sung, M.H., "Applying Six Sigma to Manufacturing Process in the Food Industry to Reduce Quality Cost." Scientific Research and Essays, vol. 6(3), pp. 580-591, (2011).

[4] Brassard, M., Finn, L., Ginn, D. and Ritter, D., "The Six Sigma Memory Jogger TM II." GOAL/QPC, (2002).

[5] Basu, R., "Implementing Six Sigma and Lean: A Practical Guide to Tools and Techniques." Hungary: Butterworth-Heinemann, (2009).

[6] Tang, L.C., Goh, T. N., Yam, H.S. and Yoap, T., "Six Sigma Advanced Tools for Black Belts and Master Black Belts." John Wiley and sons Itd., England, (2006).

[7] Pyzdek, T. and Keller, P.A., " A Complete Guide for Green Belts,Black Belts, and Managers at All Levels." The McGraw-Hill Companies, (2010).

[8] Eckes, G., "Six Sigma for Everyone." John Wiley and Sons, New Jersey, (2003).

[9] Lange, K. A., Leggett, S.C., and Baker, B., "Potential Failure Mode and Effects Analysis (FMEA)-Reference Manual" DaimlerChrysler Corporation, Ford Motor Company, General Motors Corporation, (2001). 


\section{LIST OF TABLES}

Table 1. Details of project charter.

\begin{tabular}{|c|c|}
\hline Project Title & $\begin{array}{l}\text { Reduction of rejected thermoformed } \\
\text { refrigerator inner liners }\end{array}$ \\
\hline Business case & $\begin{array}{l}\text { Due to excess reject, production cost } \\
\text { increases and the profit margin } \\
\text { decreases. }\end{array}$ \\
\hline Problem Statement & $\begin{array}{l}\text { Total defect ratio in thermoforming } \\
\text { process in period from Jan. to June } 2010 \\
=12.3 \% \text { (avg.) }\end{array}$ \\
\hline In Scope & Defect ratio : thermoforming process \\
\hline Out Scope & All other manufacturing processes \\
\hline Expected customer $\mathrm{B}$ & Reduction in manufacturing cost. \\
\hline
\end{tabular}

Table 2. SIPOC of thermoforming process.

\begin{tabular}{|c|c|c|c|c|}
\hline Suppliers & Inputs & Process & Outputs & Customers \\
\hline Sheet extrusion & $\begin{array}{c}\text { ABS Sleets with } \\
\text { determined specifications }\end{array}$ & Sheet Supply & \multirow{2}{*}{$\begin{array}{l}\text { Trimmed } \\
\text { Inner liner }\end{array}$} & \multirow{2}{*}{$\begin{array}{l}\text { Pre assy: } \\
\text { Department } \\
\text { for inner liner }\end{array}$} \\
\hline \multirow{8}{*}{$\begin{array}{l}\text { production } \\
\text { engineering }\end{array}$} & Working instructions & \multirow{2}{*}{$\begin{array}{l}\text { Vacuum } \\
\text { Forming }\end{array}$} & & \\
\hline & Inspection instructions & & \multirow{2}{*}{$\begin{array}{c}\text { nonconforming } \\
\text { products }\end{array}$} & \multirow{2}{*}{ C'rusher } \\
\hline & Gained operators & \multirow{2}{*}{$\begin{array}{l}\text { Inner liner } \\
\text { inspection }\end{array}$} & & \\
\hline & $\begin{array}{l}\text { MIoulds for inner liner } \\
\text { (vacuum forming) }\end{array}$ & & \multirow{2}{*}{$\begin{array}{l}\text { Defect analysis } \\
\text { presentation }\end{array}$} & \multirow{4}{*}{$\begin{array}{c}\text { Top } \\
\text { management } \\
\text { and all } \\
\text { concerned } \\
\text { suppliers and } \\
\text { customers }\end{array}$} \\
\hline & $\begin{array}{c}\text { Vacuum forming } \\
\text { Machines }\end{array}$ & \multirow{2}{*}{ Trimming } & & \\
\hline & Hydraulic presses & & \multirow{2}{*}{$\begin{array}{l}\text { Production } \\
\text { records }\end{array}$} & \\
\hline & $\begin{array}{c}\text { cutter's and pier cing } \\
\text { levices }\end{array}$ & \multirow{2}{*}{$\begin{array}{l}\text { Trimmed inner } \\
\text { liner inspection }\end{array}$} & & \\
\hline & $\begin{array}{c}\begin{array}{c}\text { Trimming and piercing } \\
\text { Dies }\end{array} \\
\end{array}$ & & \multirow{3}{*}{$\begin{array}{l}\text { Feed back to } \\
\text { main supplier }\end{array}$} & \multirow{3}{*}{$\begin{array}{c}\text { Sheet } \\
\text { Extrusion } \\
\text { Department }\end{array}$} \\
\hline Planing & production plan & \multirow{2}{*}{$\begin{array}{c}\text { Delivery to Pre } \\
\text { Assy. }\end{array}$} & & \\
\hline Maintenance & Mraintenance instructions & & & \\
\hline
\end{tabular}


Table 3. Failure mode and effects analysis (FMEA).

\begin{tabular}{|c|c|c|c|c|c|c|c|c|c|}
\hline \multirow{2}{*}{$\begin{array}{l}\text { potential failure } \\
\text { mode }\end{array}$} & \multirow{2}{*}{$\begin{array}{c}\text { potential effect of } \\
\text { failure }\end{array}$} & \multirow{2}{*}{$\begin{aligned} \text { severity } \\
\text { (SEV.) }\end{aligned}$} & \multirow{2}{*}{ potential causes of failure } & \multirow{2}{*}{$\begin{array}{c}\text { occurrence } \\
(0 \mathrm{CC} .)\end{array}$} & \multicolumn{2}{|c|}{ current control } & \multirow{2}{*}{$\mid \begin{array}{c}\text { Detection } \\
\text { (DET.) }\end{array}$} & \multirow{2}{*}{$\begin{array}{c}\text { risk periority } \\
\text { number (R.P.N.) }\end{array}$} & \multirow{2}{*}{ Recommended actions } \\
\hline & & & & & prevention & detection & & & \\
\hline \multirow{5}{*}{$\begin{array}{c}\text { black hard } \\
\text { particlesin sheet } \\
\text { layers and } \\
\text { consequently in } \\
\text { vacuum formed } \\
\text { inner liner layers }\end{array}$} & \multirow{5}{*}{$\begin{array}{l}\text { Reject home } \\
\text { refrigerator } \\
\text { inside } \\
\text { appearance }\end{array}$} & 8 & $\begin{array}{c}\text { operation of materials with different grades } \\
\text { in the same machine }\end{array}$ & 10 & $\begin{array}{l}\text { standard operation } \\
\text { procedure (SOP) }\end{array}$ & nil & 8 & 640 & $\begin{array}{l}\text { using one type of material } \\
\text { (type B) }\end{array}$ \\
\hline & & 8 & Screw and Barrel not clean & 10 & nil & nil & 9 & 720 & screw and barrel cleaning \\
\hline & & 8 & inadequate screen changing period & 7 & $\begin{array}{l}\text { standard operation } \\
\text { procedure (SOP) }\end{array}$ & $\begin{array}{l}\text { pressure trend on } \\
\text { screen monitor }\end{array}$ & 8 & 448 & $\begin{array}{l}\text { design an experiment to get } \\
\text { the optimum setting using } \\
\text { (DOE) }\end{array}$ \\
\hline & & 8 & inadequate filter screen mesh & 8 & $\begin{array}{l}\text { classification of } \\
\text { screen filters }\end{array}$ & nil & 5 & 320 & $\begin{array}{l}\text { design an experiment to get } \\
\text { the optimum setting using } \\
\text { (DOE) }\end{array}$ \\
\hline & & 8 & Feed die not clean & 10 & nil & nil & 9 & 720 & $\begin{array}{l}\text { Feed die cleaning and } \\
\text { maintenance }\end{array}$ \\
\hline \multirow{4}{*}{$\begin{array}{c}\text { non uniform } \\
\text { sheet thickness } \\
\text { over sheet width }\end{array}$} & \multirow{4}{*}{$\begin{array}{l}\text { Reject home } \\
\text { refrigerator } \\
\text { inside } \\
\text { appearance }\end{array}$} & 8 & $\begin{array}{c}\text { operation of materials with different grades } \\
\text { in the same machine }\end{array}$ & 10 & \begin{tabular}{|l} 
standard operation \\
procedure (SOP) \\
\end{tabular} & nil & 8 & 640 & $\begin{array}{c}\text { using one type of material } \\
\text { (type B) }\end{array}$ \\
\hline & & \multirow{2}{*}{8} & \multirow{2}{*}{ not appropriate measurement system } & \multirow{2}{*}{8} & \multirow{2}{*}{ nil } & \multirow{2}{*}{ nil } & \multirow{2}{*}{5} & \multirow{2}{*}{320} & training plan for inspectors \\
\hline & & & & & & & & & $\begin{array}{l}\text { caliberation plan for } \\
\text { measurement device }\end{array}$ \\
\hline & & 8 & inadequate filter screen mesh & 8 & $\begin{array}{l}\text { classification of } \\
\text { screen filters }\end{array}$ & nil & 5 & 320 & $\begin{array}{l}\text { design an experiment to get } \\
\text { the optimum setting using } \\
\text { (DOE) }\end{array}$ \\
\hline
\end{tabular}

Table 4. Factors and levels used for designing the experiment.

\begin{tabular}{|c|c|c|c|c|c|c|}
\hline \multirow{4}{*}{ Trial order } & \multicolumn{9}{|c}{ factors and levels } \\
\cline { 2 - 7 } & screen change period (hrs) & \multicolumn{2}{c|}{ screen mesh no. } & \multicolumn{2}{c|}{ feeding dies heaters $\left({ }^{\circ} \mathrm{C}\right)$} \\
\cline { 2 - 7 } & -1 & 1 & -1 & 1 & -1 & 1 \\
\cline { 2 - 7 } & $4 \mathrm{hrs}$ & $8 \mathrm{hrs}$ & $\# 60$ & $\# 80$ & 220 & 230 \\
\hline 1 & -1 & & -1 & & & 1 \\
\hline 2 & & 1 & -1 & & & 1 \\
3 & -1 & & & 1 & & 1 \\
4 & -1 & & -1 & & -1 & \\
5 & & 1 & -1 & & -1 & \\
6 & -1 & & & 1 & -1 & \\
7 & & 1 & & 1 & -1 & \\
8 & & 1 & & 1 & & 1 \\
\cline { 2 - 7 } & & & & & & \\
\end{tabular}




\section{LIST OF FIGURES}

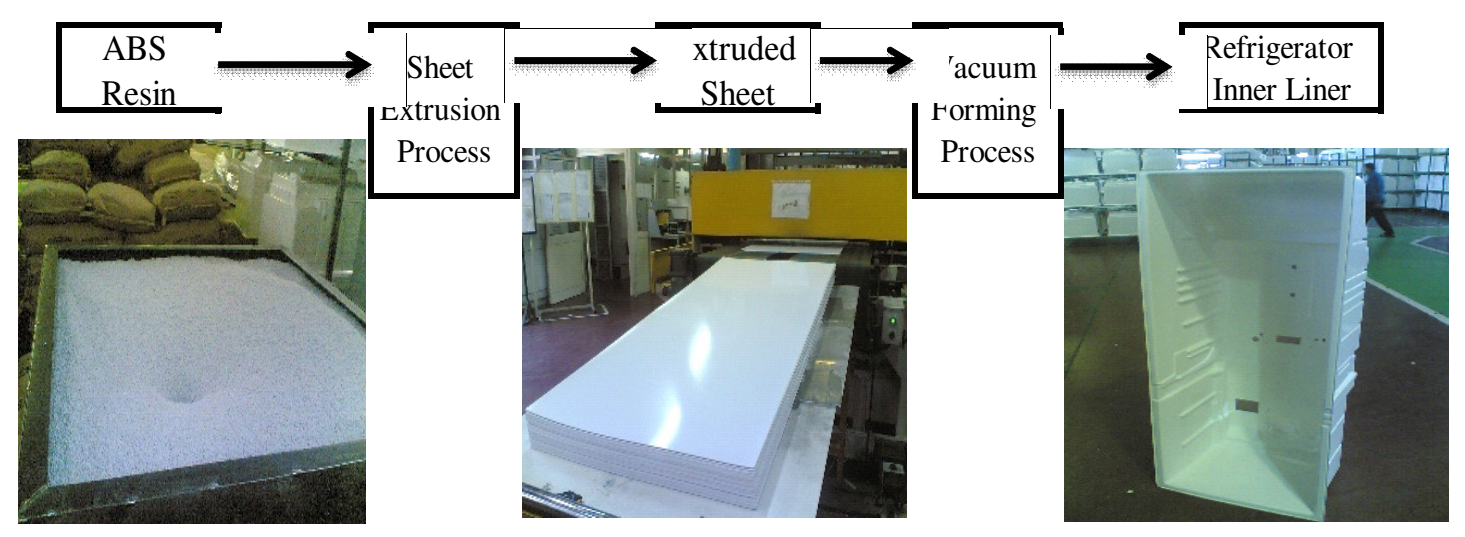

Figure 1. Process flow map.

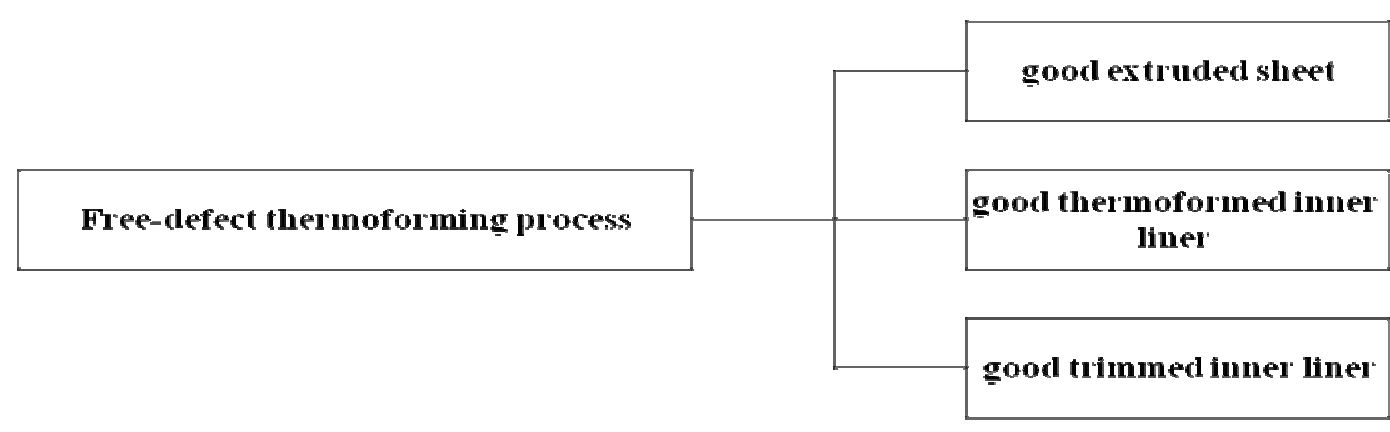

(Need)

(Requirements)

Figure 2. Critical to quality tree.

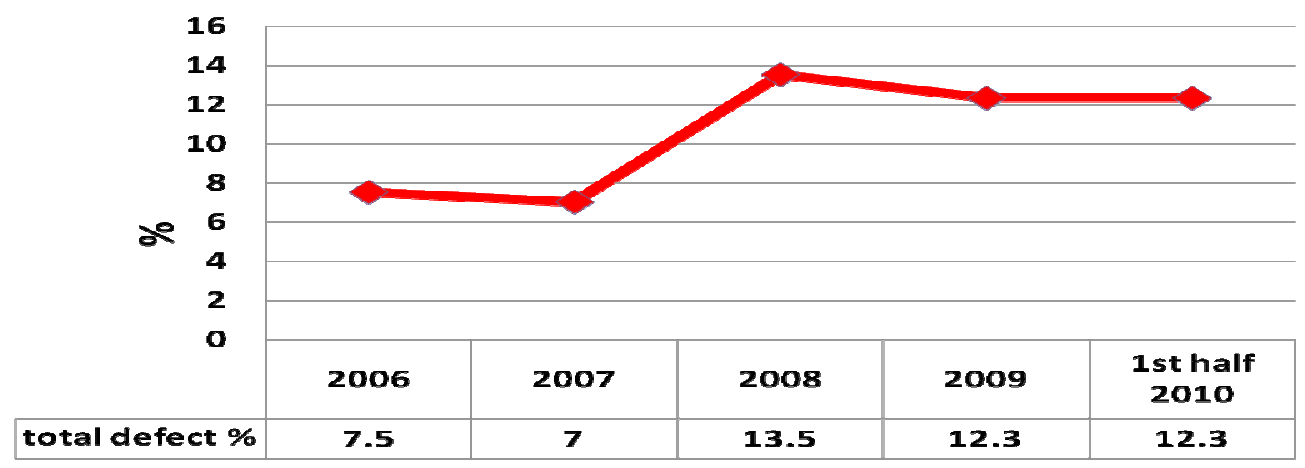

Figure 3. Defect ratio for thermoforming process. 


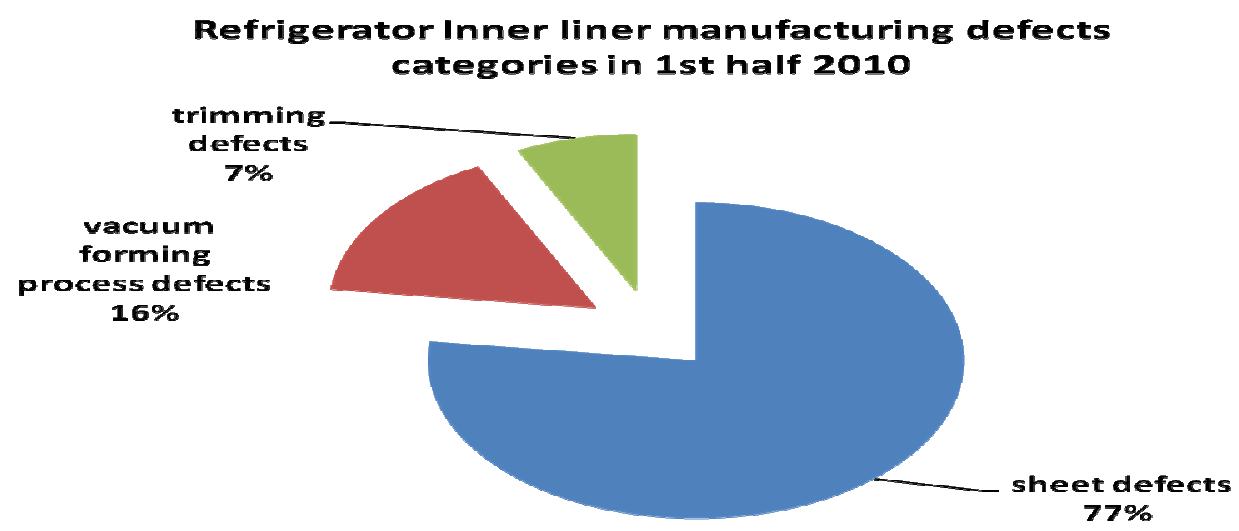

Figure 4. Defects categories participation in total defect ratio.

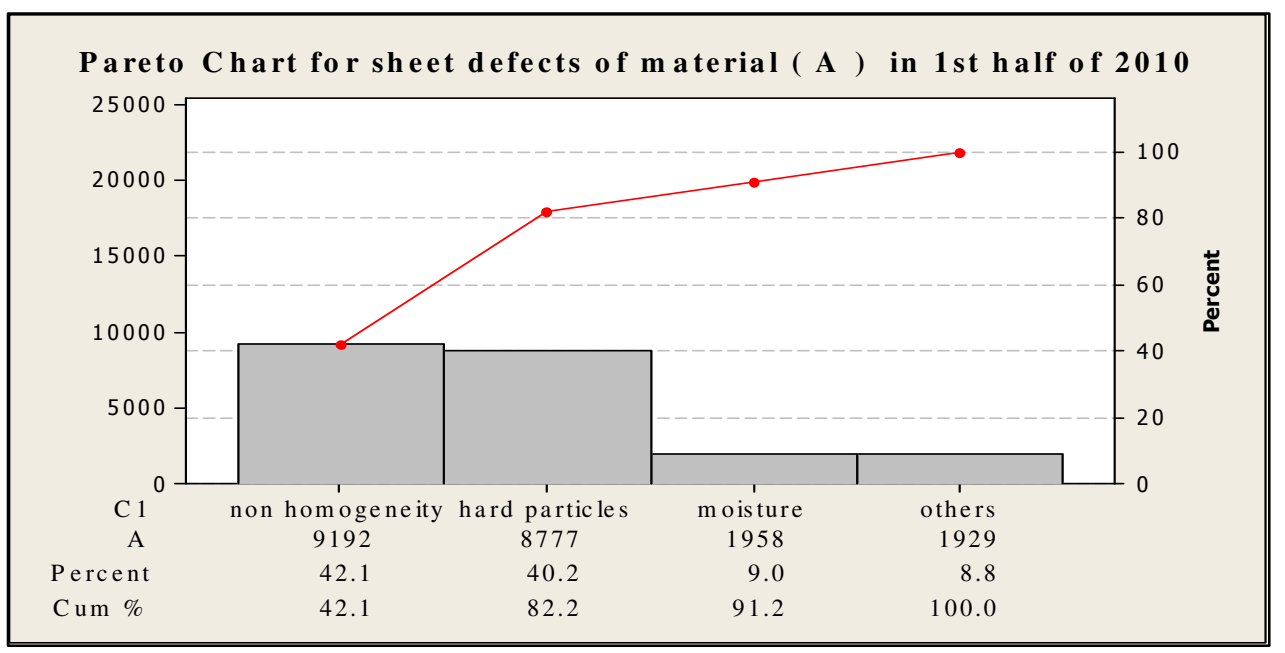

Figure 5. Pareto chart for vital few defects of material (A).

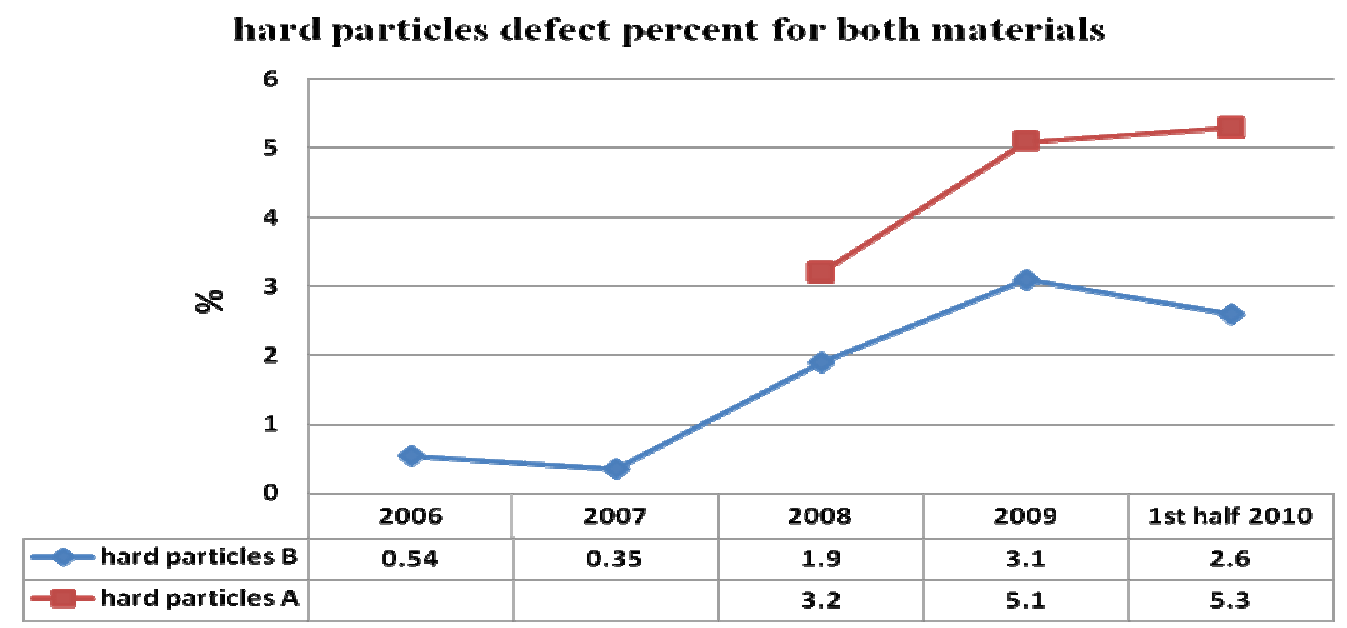

Figure 6. Base line for hard particles defect for material A and B. 


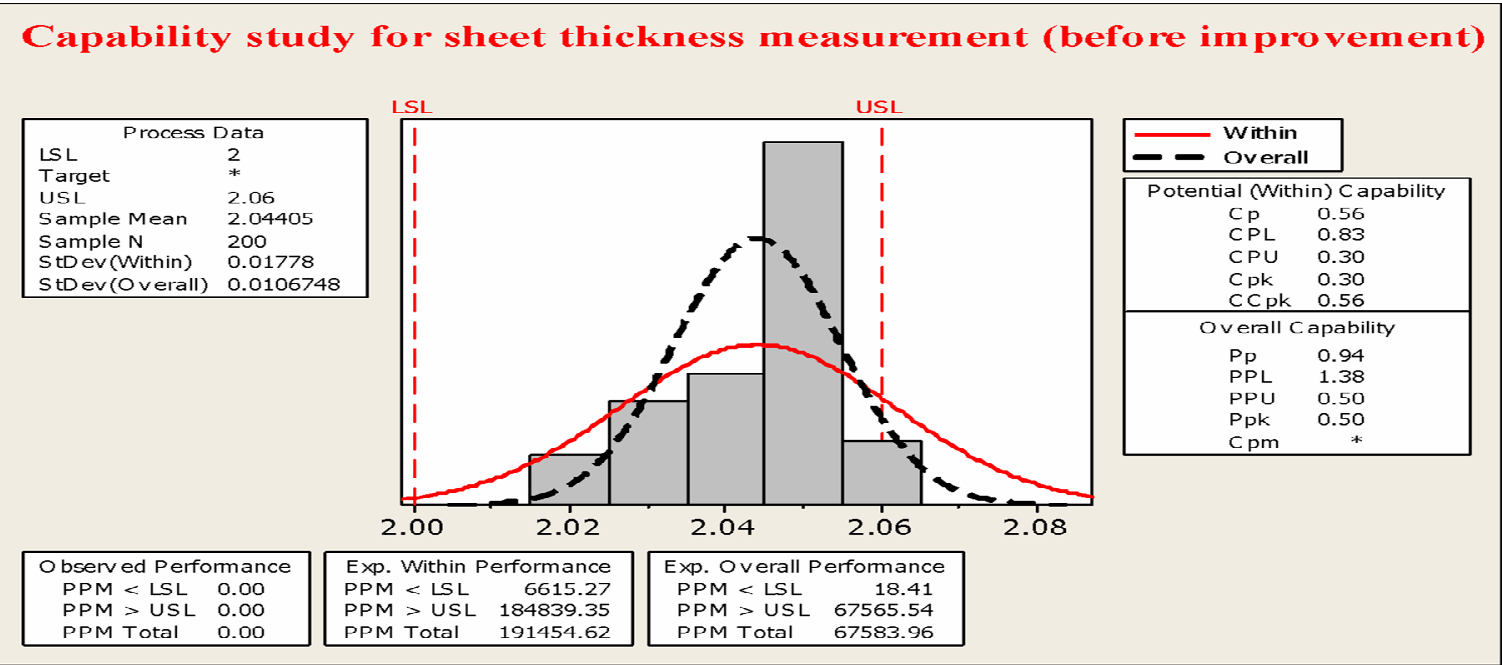

Figure 7. Process capability for sheet thickness uniformity (base line).

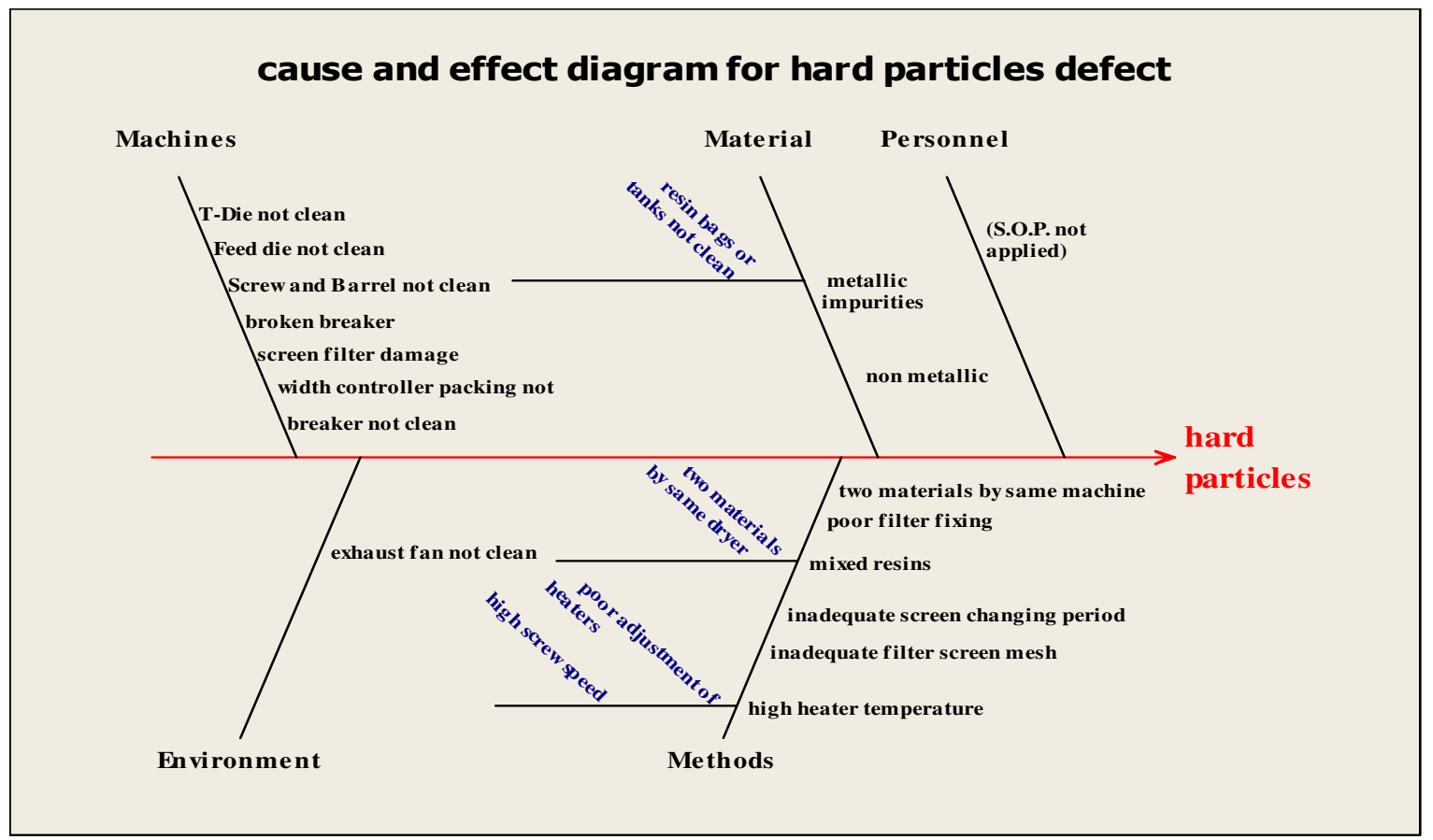

Figure 8. Cause and effect diagram (fish bone) for hard particles defect. 


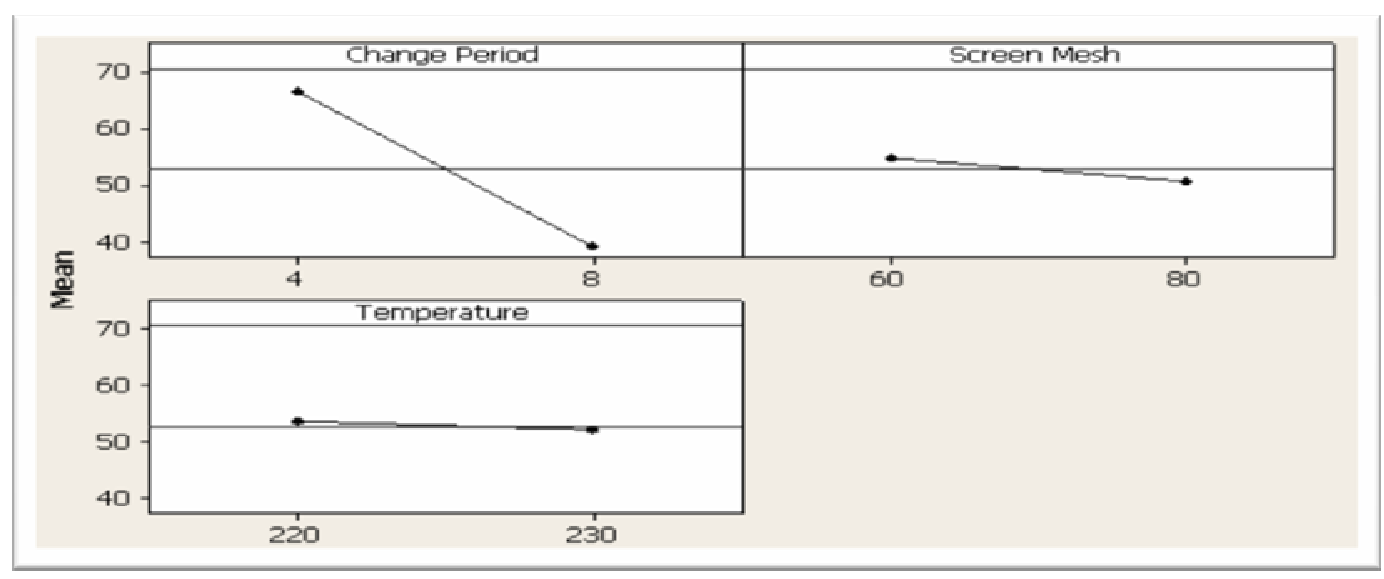

Figure 9. Main effects of parameters setting levels on mean defects ratio.

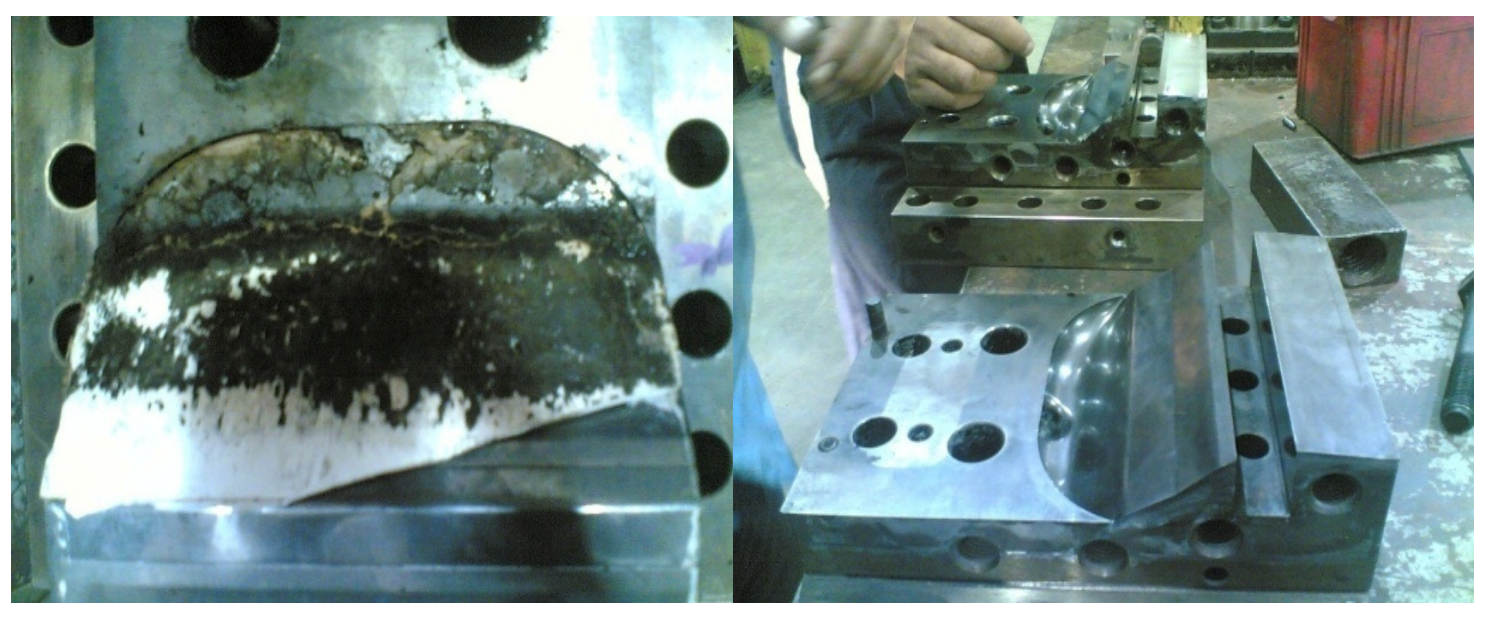

Before

After

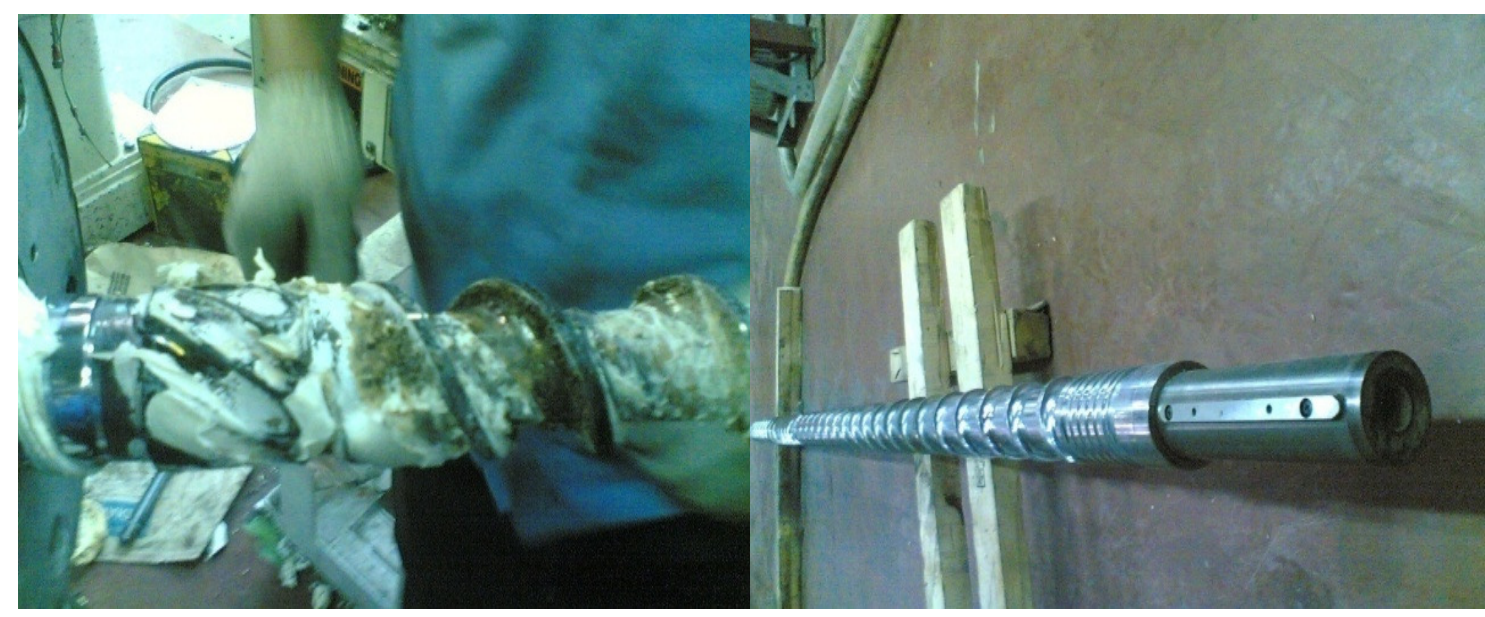

Before

After

Figure 10. Photos of (screw and feed die) before and after cleaning. 


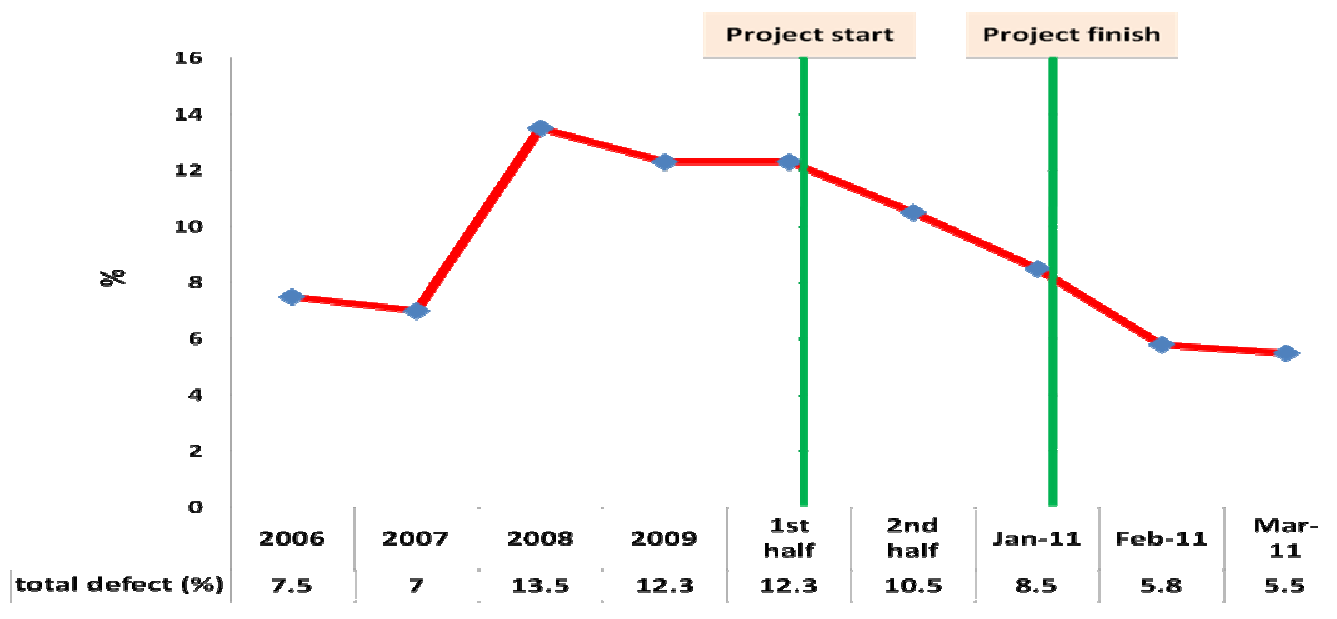

Figure 11. Total defect percent in refrigerator inner liner manufacturing department.

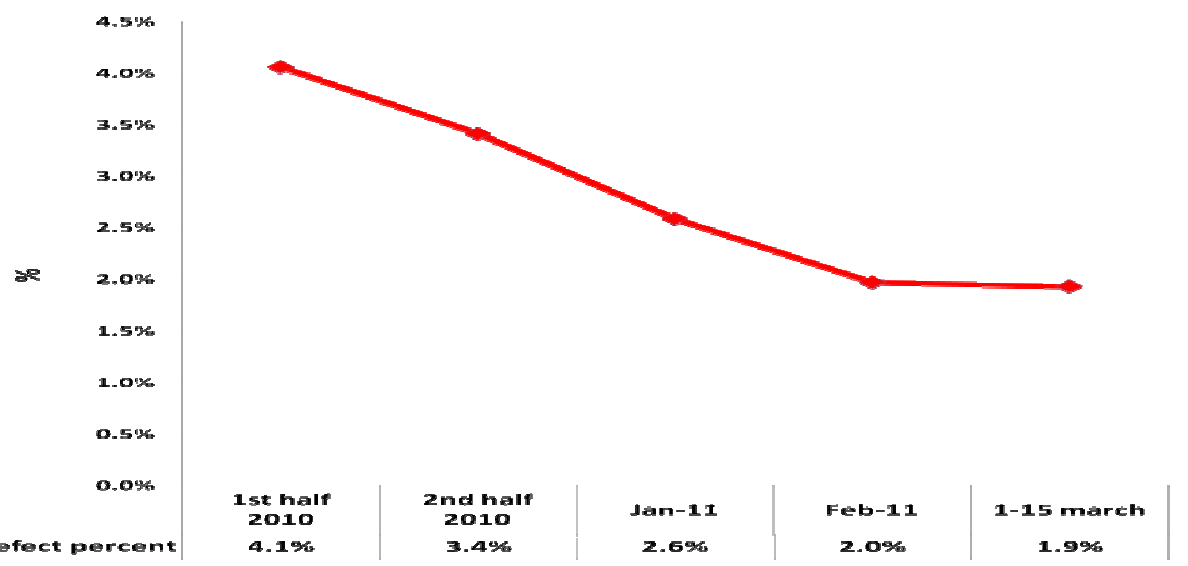

Figure 12. Hard particles defect percent monitoring after improvement. 


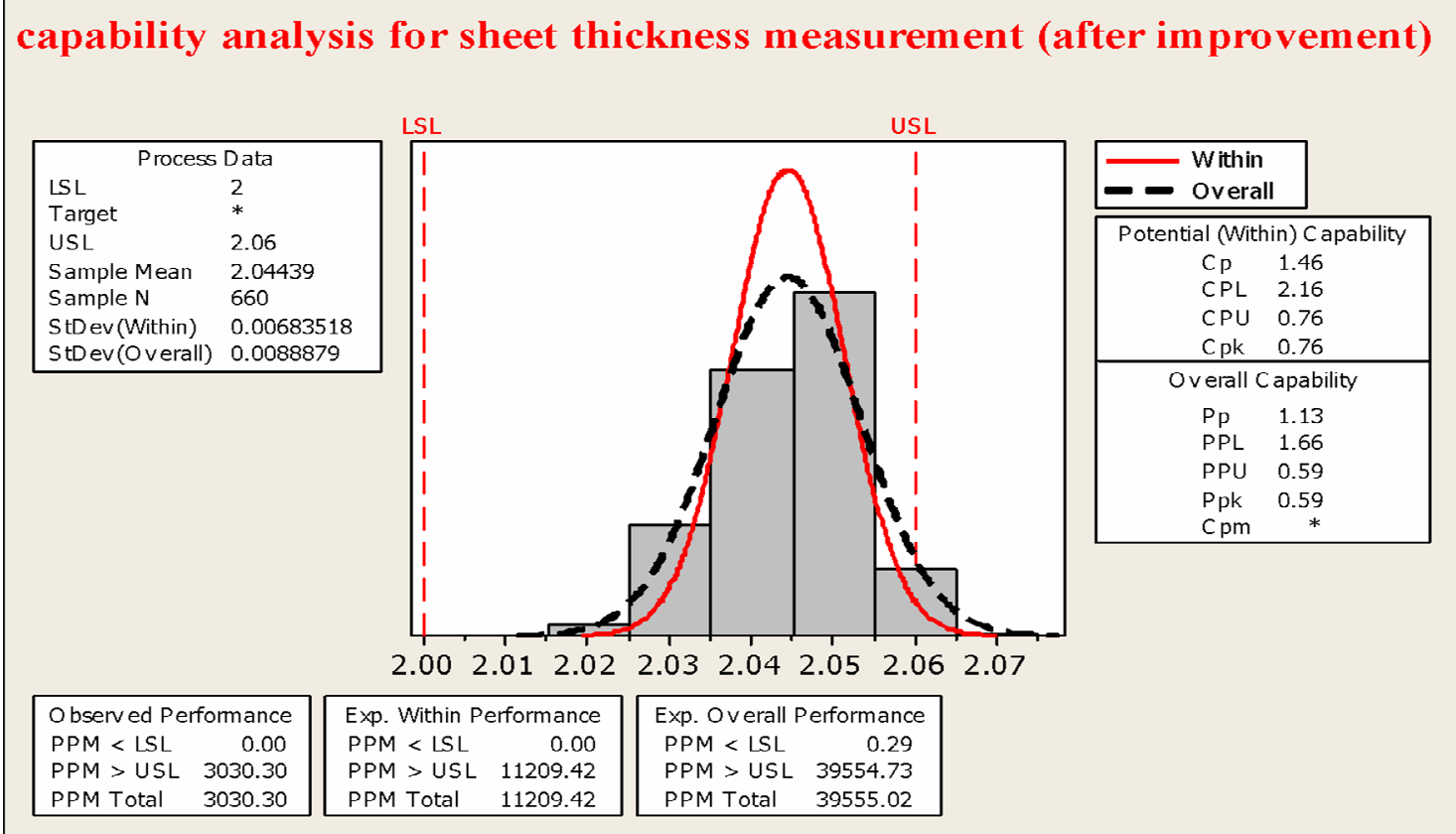

Figure 13. Process capability for sheet thickness measurement after using one material (type B).

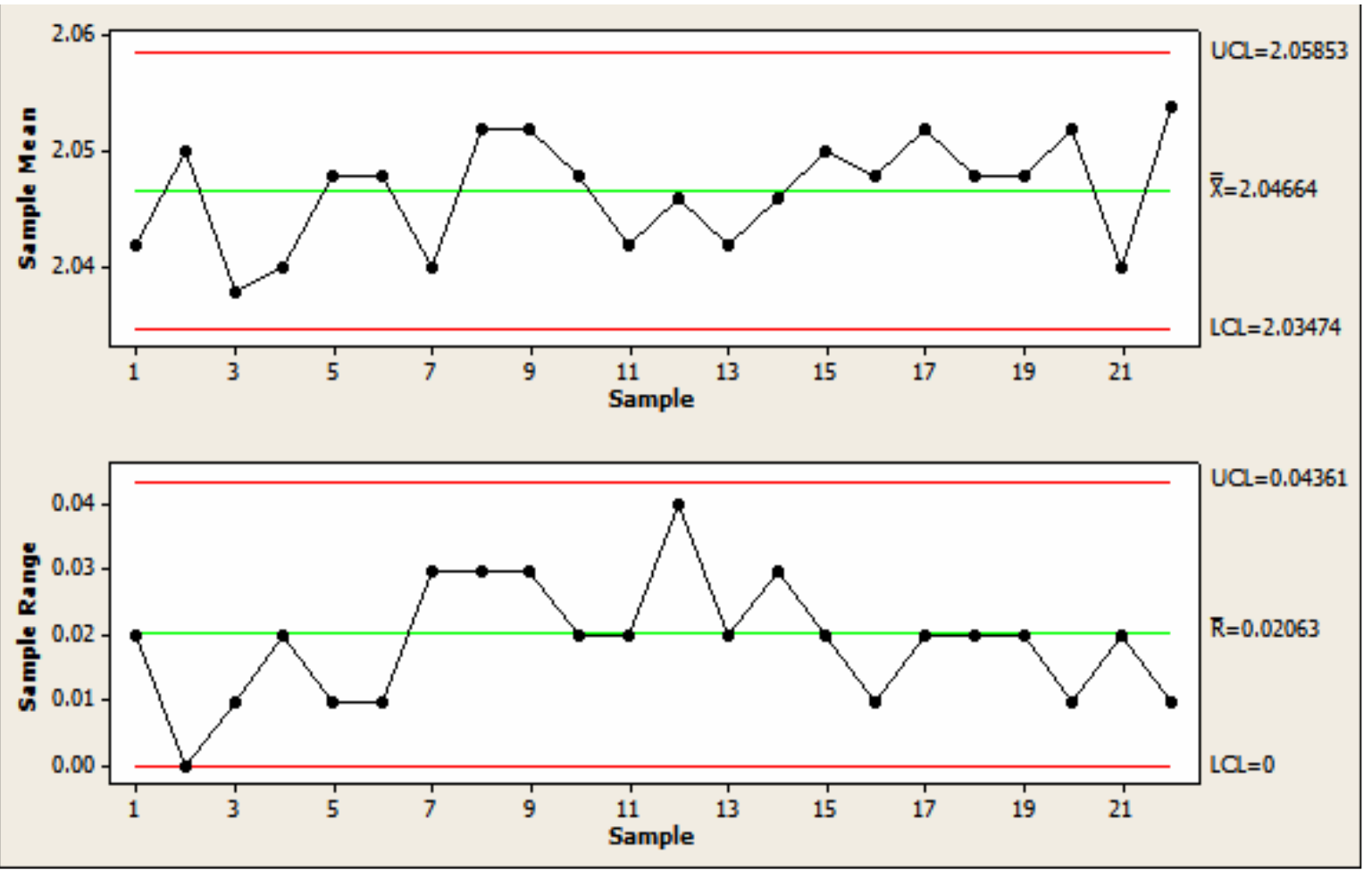

Figure 14. Variable control charts for sheet thickness measurement. 